\title{
EFFICIENCY OF INDOOR ENVIRONMENT FOR IMPROVING PEOPLE'S HEALTH
}

\author{
Imad Assali \\ Assistant Professor / Chairperson of Interior Design Department, College of Arts, Science \& Education, Ahlia \\ University, Kingdom of Bahrain, email: iassali@ahlia.edu.bh
}

\begin{abstract}
The main role of building is to provide shelter, security and healthy place for its occupants. As people spend most of their time in indoor space ( home, work, schools, etc.) therefore most of the hazards that affect human health is a result of poor indoor environment. Among many factors contribute to unhealthy indoor environment and affect people' health are lack of maintenance, indoor air quality (IAQ) as a result of poor of ventilation, light, noise, etc. Nowadays, architects, and interior designers main objective is to promote comfort and healthy indoor building environment for its occupants through the design process of new building and provide proper design solutions for existing buildings. Therefore, the aim of this research is identify active factors related health that affect the indoor building environment. Strategies and recommendations to prevent or minimize hazards due to poor indoor environment will be also addressed.
\end{abstract}

Keywords: sustainable, indoor air quality (IAQ), human health

\section{INTRODUCTION}

The main requirement of any building is to provide healthy and comfortable environment for its people. Thus, buildings must be designed, constructed and managed in a way to prevent risks to the health of the occupants (AJAYI et, al., [1]. As the majority of people spend approximately $93 \%$ of their time in indoor environment (residences, offices, schools, shopping centers, etc.) and among those buildings, our home has the highest effects on our health, security and wellbeing. Therefore, designers should create 'interior architectural projects' that have a low negative environmental impact on occupants' health. The symptoms of sickness that building occupants suffer such as itchy, running nose, dry throat and skin, headache, itchy eyes and so on are as a result of poor design, improper ventilation and most of these the materials used in construction and furniture that contribute to indoor air pollution. (Grobman et, al., [2] stated that " the indoor environment is responsible for $3 \%$ of all morbidity and mortality worldwide, making it the 9th leading contributing cause of disease" $^{1}$.

However, this paper will focus on indoor building environment in relation to health issues, it will address the sources of hazards that contribute to occupants' health and comfort. Then this paper will introduce design guidelines for mitigating negative effects of these hazards.

\subsection{Research Aims \& Objectives}

This research aims at introducing specific interior design elements for buildings to improve the indoor environmental, to achieve this aim the following research objectives were developed:
- Study the contemporary sustainable models and guiding principles.

- Present guidelines, which could help the architects, designers and the decision makers to turn their buildings towards sustainability.

\subsection{Research Problem}

People became more aware of the seriousness of environment deterioration and the importance of sustainable development. The main problem of this paper is how to formulate design criteria and guidelines to provide healthy and sustainable interior environment.

\subsection{Research Methods}

To reach the research aims and objective this paper reviewed literatures in relation to indoor building environment and its impact on occupants' health. It will also check the experience in sustainable practices of buildings. Finally, evaluate different approaches according to the sustainable design principles.

\section{SOURCES OF INDOOR CONTAMINANTS}

Source of pollutants can be classified into two main categories: Indoor materials \& Inhabitant's activities and life styles ( see figure 1).

\footnotetext{
${ }^{1}$ Grobman, Y., Amster, E., 2011, Implications of Green Buildings and Climate Change on Human Health in Israel, Geography Research Forum • Vol. 31 • 2011: 70-82, http://grobman.net.technion.ac.il/files/2013/01/Implicationsof-Green-Buildings-and-Climate.pdf, p:71
} 


\subsection{Indoor Materials}

One of the major risk of indoor environment that affecting occupant health is the indoor materials. Table 1shows the materials used in buildings and its impact on human health.

Table 1: Material used in Buildings(source: the Author)

\begin{tabular}{|l|l|}
\hline \multicolumn{1}{|c|}{ Material } & \multicolumn{1}{c|}{ Description } \\
\hline Paints & $\begin{array}{l}\text { - toxic } \\
\text { - humidity problem in a space }\end{array}$ \\
\hline $\begin{array}{l}\text { carpets, wood, wallpaper, thermal insulation materials, } \\
\text { paints, coatings, varnishes, viny1 flooring. }\end{array}$ & $\begin{array}{l}\text { Volatile Organic Compounds (VOCs) } \\
\text { Moulds: to grow need moisture, warm temperature and low air }\end{array}$ \\
\hline $\begin{array}{l}\text { Plants } \\
\text { Polyvinyl Chloride (PVC) }\end{array}$ & $\begin{array}{l}\text { - reduce the CO2 and the relative humidity } \\
\text { - lower the temperature of the room }\end{array}$ \\
\hline $\begin{array}{l}\text { Radon sources } \\
\text { - Construction materials such as blocks that emit radon } \\
\text { - Gas that emanates up from the soil and rocks into } \\
\text { basements and lower floors. }\end{array}$ & - PVCs can cause birth defects, cancer \\
\hline
\end{tabular}

\subsection{Inhabitant's Activities and Lifestyles}

Some of the indoor pollutants results from inhabitants activities and can be very harmful. Among these pollutants:

- carbon dioxide that result from combustion of fuel.

- Tobacco Smoke that cause odor and asthma

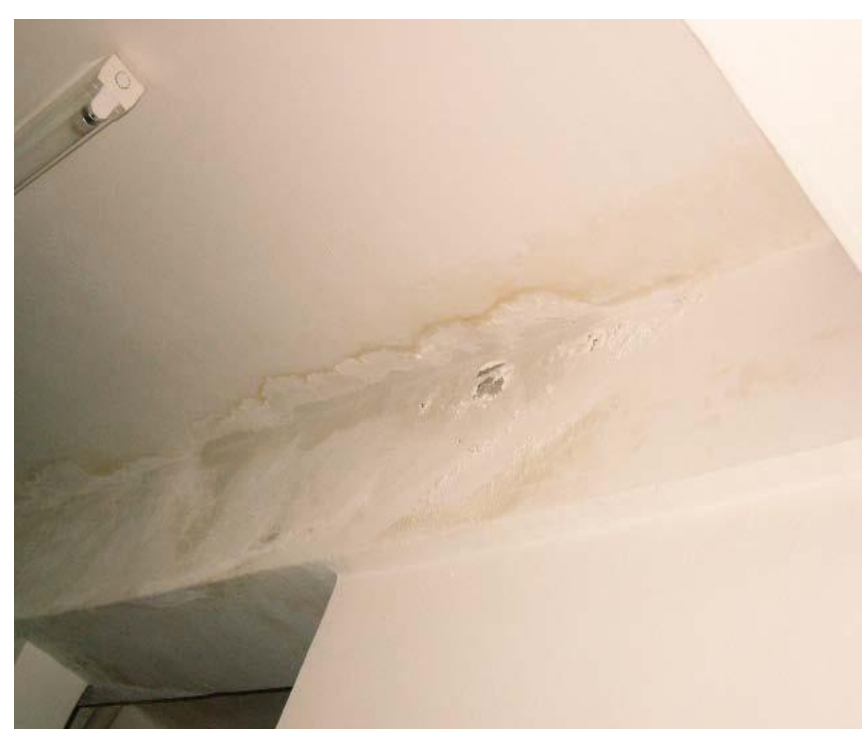

The dampness effects at the beam due to minor leakage from the above wet area.

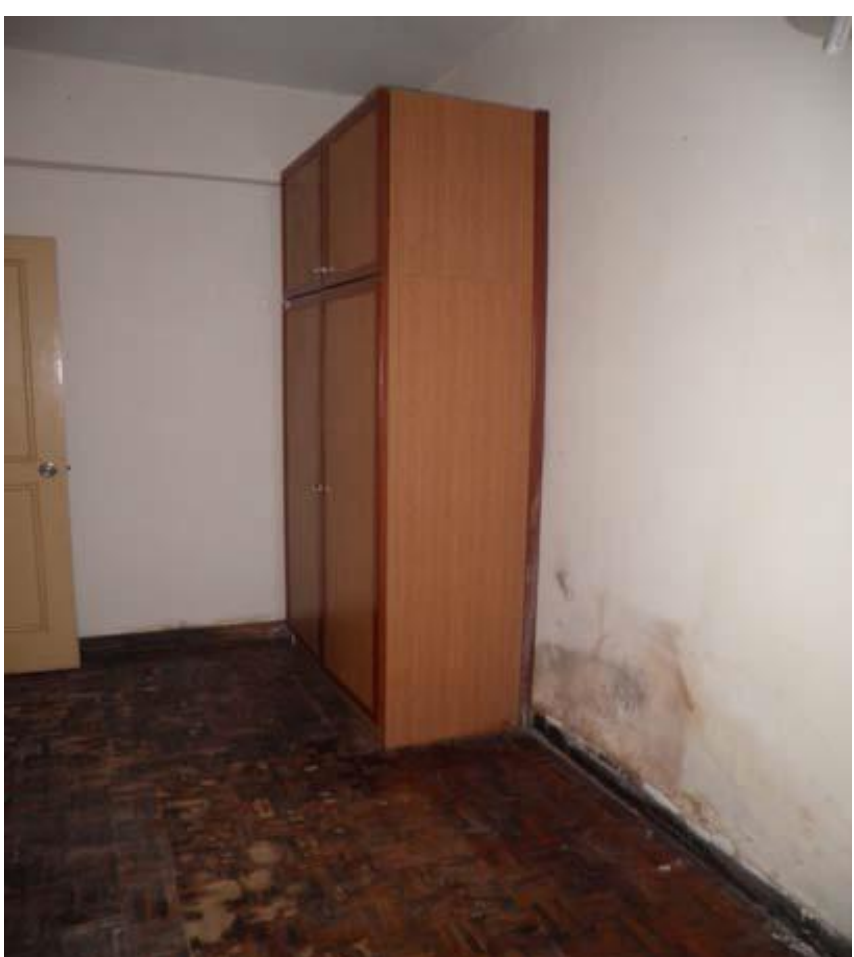

stained wall affecting the wardrobe and floor parquet timber material 


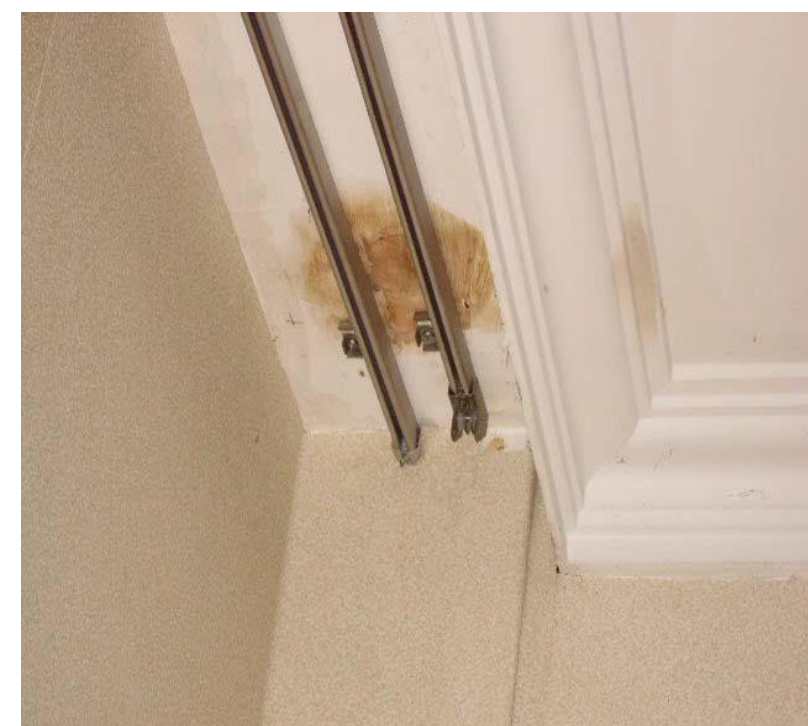

The effect of dampness at this curtain railing in the gypsum false ceiling.

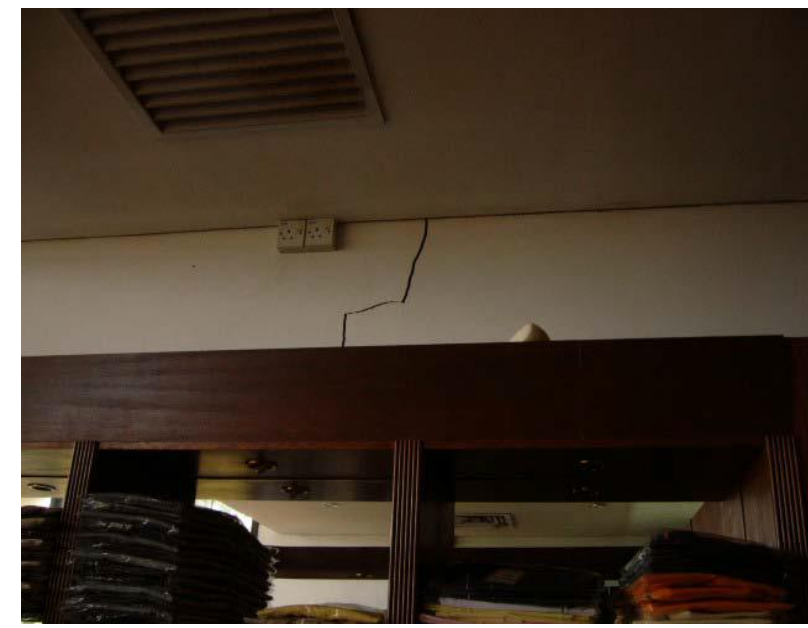

Cracks appears in a beam one of the main building structure

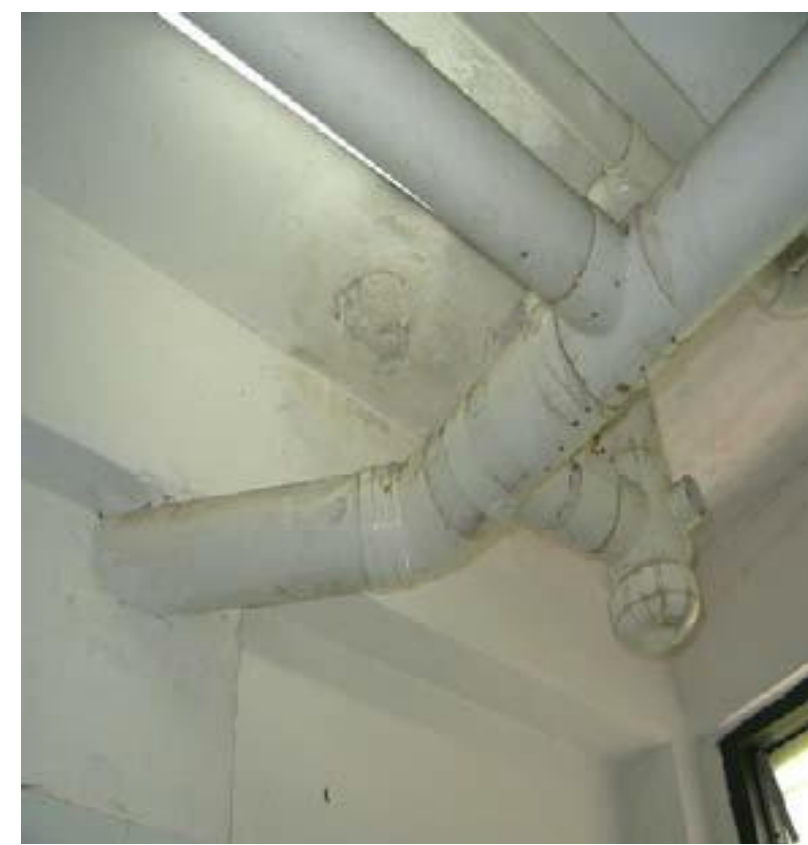

Concrete leakage with clear stained marked on it.

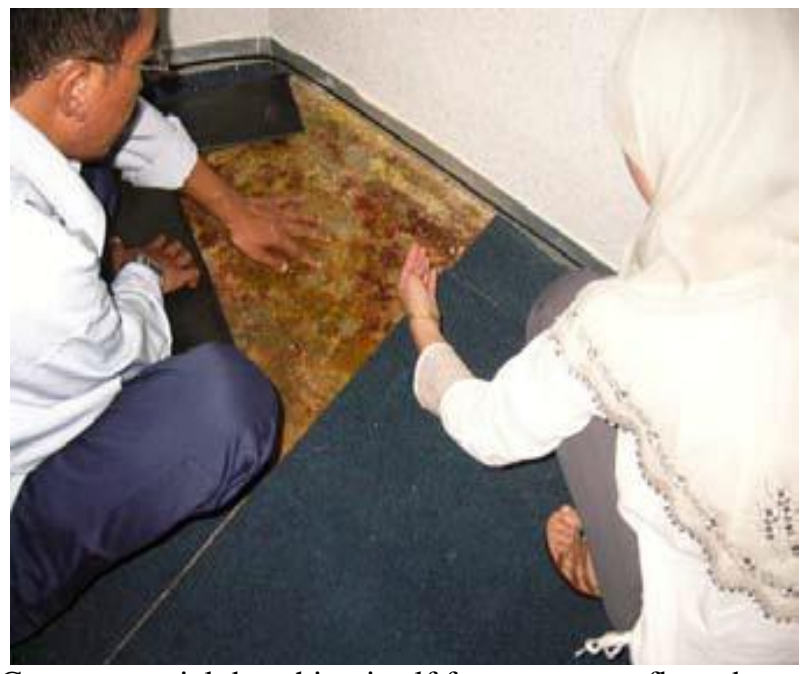

Carpet material detaching itself from concrete floor due to water seepage.

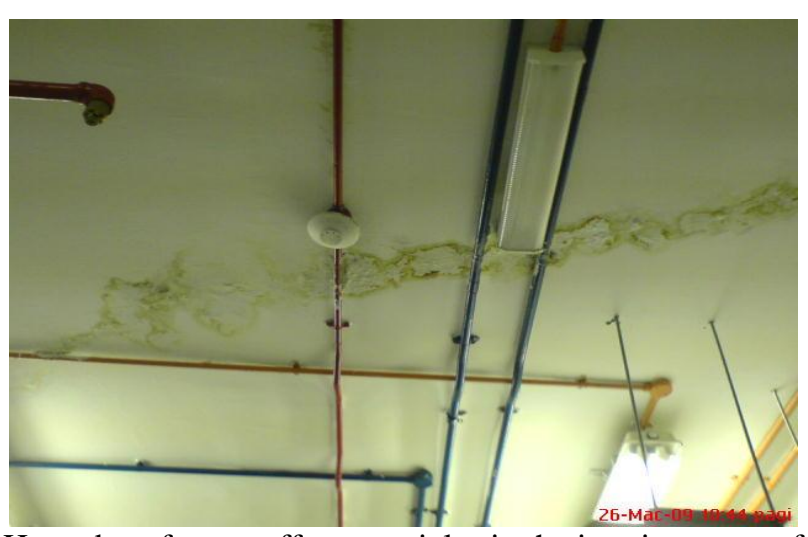

Hazardous fungus effects particles in the interior space of this leakage concrete

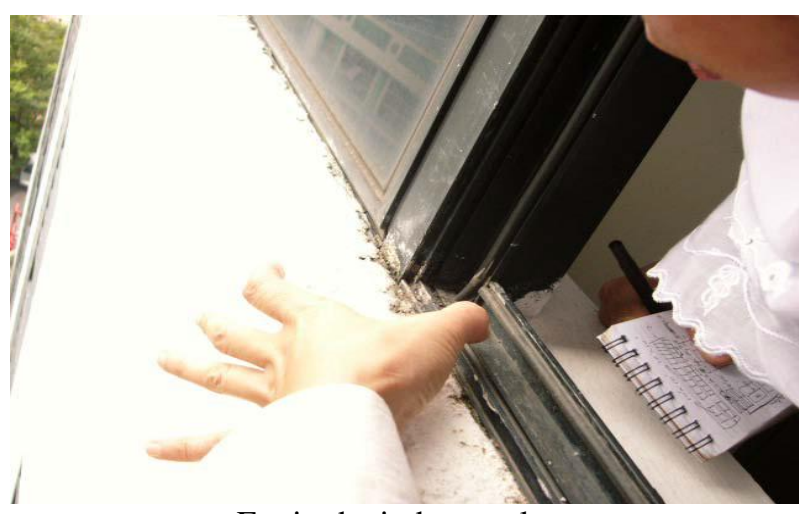

Expired window sealant

Figure 1: Details revealing the interior buildings defects (Source: Talib et, al., [6].

\section{THEORETICAL REVIEW}

Generally, the building indoor environment hazards on occupants health are more as people spend more time indoors. In the context of global industries natural disasters have unexpectedly occurred at various places in the world due to global warming and abnormal changes of climates, in this context the issue of sustainability had emerged. The term of sustainability is a very technical term affecting 
everything an individual does. Ayalp, [3] stated that building during its life cycle should provide people during their stay with satisfaction and comfort without threaten to their health.

Therefore to achieve sustainable development, there should be some principles to be observed.

- Implementation and sustaining the use of renewable solar and wind resources

- Optimizing the use of resources and minimizing natural resource consumption that proportionately is less than their natural growth.

- Minimum production of wastes and pollution that can be absorbable in local to global environment scale.

- Providing basic needs of human and society and creating a healthy environment for future generations.

Finally, designers have a responsibility in creating sustainable interior environments to fulfill human needs.
The part of this research shed light on common causes as well as mitigation measures of indoor related health risk, this section identifies some causative agents and explores their design and legislative solutions ( see figure 2) and table 2 .

\section{Attributes Indicators}

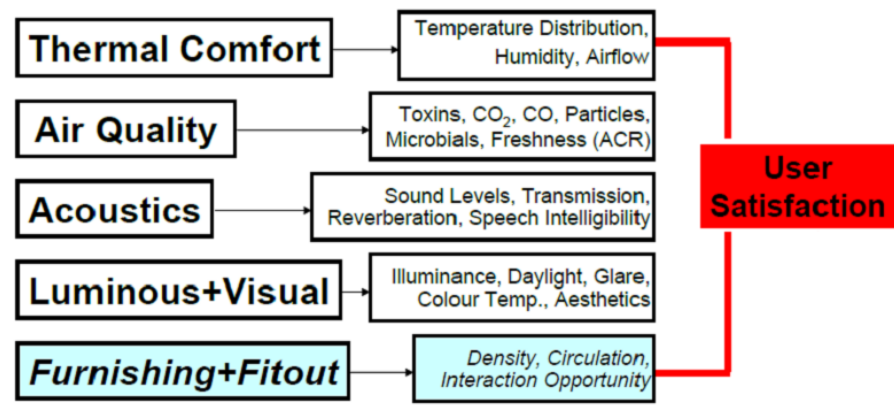

Figure 2: Healthy Indoor Environment

\section{STRATEGIES FOR HEALTHY INDOOR}

\section{ENVIRONMENT}

\begin{tabular}{|c|c|c|}
\hline Energy & Indoor Climate & Environment (surroundings) \\
\hline $\begin{array}{l}\text { Energy design/Type of energy: } \\
\text { - Space heating } \\
\text { - Water heating } \\
\text { - Ventilation } \\
\text { - Cooling and air conditioning } \\
\text { - Electricity for tech. installations } \\
\text { - Electricity for lightning } \\
\text { - Electricity for appliances } \\
\text { Natural design solutions: } \\
\text { - Passive solar energy } \\
\text { - Daylight utilisation } \\
\text { - Natural ventilation } \\
\text { - Shading during cooling season } \\
\text { - Integrated solutions } \\
\text { - User behaviour } \\
\text { Renewable energy: } \\
\text { - Energy demand } \\
\text { - Energy supply } \\
\text { - Source of renewable energy }\end{array}$ & $\begin{array}{l}\text { Light: } \\
\text { - Daylight } \\
\text { - Direct sunlight availability } \\
\text { Thermal environment: } \\
\text { - Maximum operative temperature } \\
\text { - Minimum operative temperature } \\
\text { - Adjustability (individual control) } \\
\text { Indoor air quality: } \\
\text { - Air change } \\
\text { - Minimum air change } \\
\text { Acoustics: }\end{array}$ & $\begin{array}{l}\text { Resources and emission: } \\
\text { - Re-use of materials } \\
\text { - Minimized use of virgin non- } \\
\text { renewable materials } \\
\text { - Minimized use of non-renewable } \\
\text { fuel resources } \\
\text { - Minimize life-cycle emissions of } \\
\text { greenhouse gasses } \\
\text { Characteristics and culture: } \\
\text { - To be defined in future process }\end{array}$ \\
\hline $\begin{array}{l}\text { Energy design: } \\
\text { - Design } \\
\text { - Comfort } \\
\text { Natural design solutions: } \\
\text { - Design } \\
\text { - Comfort } \\
\text { Renewable energy: } \\
\text { - Design }\end{array}$ & $\begin{array}{l}\text { Light: } \\
\text { - View out } \\
\text { - Visual privacy } \\
\text { - Visual comfort } \\
\text { - Individual control } \\
\text { - Dark bedrooms at night } \\
\text { Thermal environment: } \\
\text { - An intuitive human interface } \\
\text { - Draught } \\
\text { - Natural ventilation paths } \\
\text { Indoor air quality: } \\
\text { - Individual control } \\
\text { - Low-emitting building materials } \\
\text { Acoustics: }\end{array}$ & $\begin{array}{l}\text { Resources and emission: } \\
\text { - To be defined in future process } \\
\text { Characteristics and culture: } \\
\text { - Regional building typology } \\
\text { - Regional functional tradition } \\
\text { - Potentials and constrains in local } \\
\text { climate } \\
\text { - Regional materials } \\
\text { - Harmoniously fit in landscape } \\
\text { - Impact on street- and landscapes } \\
\text { - EIA } \\
\text { - Preservation of existing values } \\
\text { - Ecological quality of the site } \\
\text { - Risks by climate changes }\end{array}$ \\
\hline
\end{tabular}

Table 2: Parameters for Healthy Indoor Environment(source: Gylling, et, al., 2011, p:3) 


\subsection{Indoor Air Quality}

The healthy indoor environment include all aspects of the indoor environment that affect occupants in indoor spaces such as light, heat view and noise. All of these elements affect the human body and need to set design criteria to reduce their impact on people. One of the most important issue to achieve healthy condition is to provide a proper ventilation. Bacon, [4] stated provide a building with ventilation can eliminate pollutants from indoor environment and improve people health. Abdou et, al.[5] added that get rid of the pollutants from indoor spaces by proper ventilation will reduce diseases percentage as it will provide a healthy environment to its occupants. Warsco et al. [6] pointed that cracks and crevices inside buildings help growth of moulds and bacteria, he addresses solutions by applying building maintenance representing in closing these cracks, using nonporous materials to prevent the growth of mold and providing ventilation to prevent condensation. A natural way to provide a building with ventilation is a building orientation which allow change of air between outside and inside through a proper window design in term of size and position.

\subsection{Climate}

The interior walls of a building with its window is responsible for heat gain in different climates. Therefore heat gain, ventilation and lighting are influenced by the building position on site (i.e. orientation). To minimize heat gain, provide natural light and provide a proper ventilation to a building the following steps should be noticed:

- In relation to climate the building in the site should adapt to receive a proper natural light, ventilation and heat gain.

- Minimizing windows in hot climate to reduce heat gain and this will provide a building with natural light by providing a skylight which also will provide a building with ventilation. In addition it will protect the building from odor and unpleasant dusty wind.

- Building typology in hot climate should be opposite to cold climate (see figure 3). Layout of Building A suits cold climate to receive extra heat from south direction, while the layout in building B is good in hot climate to minimize heat gain from the south.

NORTH

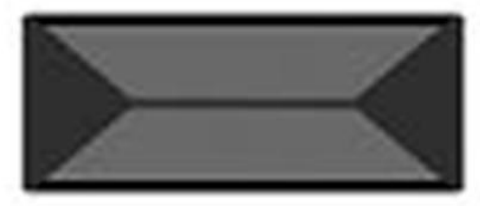

A
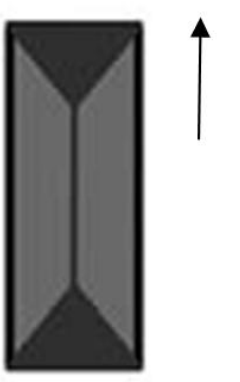

B
- Using different types of plants in the site such as evergreen or deciduous will help in controlling the microclimate and purify the air and providing shading areas around buildings (see figure 4).

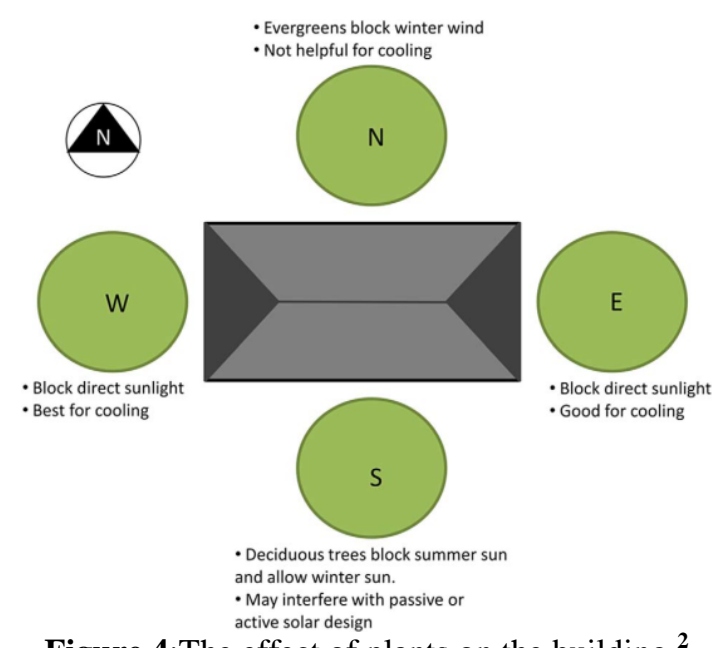

Figure 4:The effect of plants on the building ${ }^{2}$

- Controlling high temperature by natural (passive) way has a good effect on indoor environment as it will reduce depending on mechanical system (Active) which has a bad effect on indoor building condition of increasing the fuel consumption this as a result release carbon dioxide $\mathrm{CO} 2$ from the combustion of fuel, in addition of increasing the noise level resulting from machines.

- The using of machines (Active system) in providing comfort and health indoor environment needs maintenance otherwise it will increase the level of pollutants (see figure 1).

- The type of building materials affect how the building respond to the exterior environment. For example using rough materials facing the harsh climate reduce heat gain by diffusing sun rays in addition of using white colors. On the contrary using smooth and dark materials in cold climate will increase heat gain.

${ }^{2}$ Ko, Y., 2013, Urban form and residential energy use: A review of design principles and empirical findings, Journal of Planning Literature, p:339.

- Using shading devices, louvers and different roof shapes such as dome or slope roof will give shade areas and increase different air circulation around the building in reduce transmission of heat from roof to inner spaces.

- Using sound insulation material for floors and internal walls to control noise propagation inside a building.

\subsection{Maintenance}

Indoor building defects are the main reason of diseases. These defects generally happened for poor workmanship, lack of maintenance and climatic effects on the building components result from inadequacies in design. Therefore

Figure 3: Building Layout 
indoor building environment need regular check for all interior elements to keep the building healthy.

\subsection{Selection of Building Materials, Finishes and Furnishings}

In order to improve the indoor air quality it is important for interior designers to make research on the material and furniture used in indoor environment that prevent the emission of volatile organic compounds (VOC). As materials with low emitting products contribute to the reduction of indoor air pollution. Warsco et, al., [6] stated that designer's choices and awareness regarding indoor materials can prevent indoor pollutions and support healthy environment. Besides providing a building with a proper ventilation can also help to reduce the concentration of indoor pollutants.

\section{CONCLUSION AND RECOMMENDATION}

Indoor environment is a crucial part of the design process; therefore, designers need to change their thinking about this physical environment and increase their awareness of health impact on occupants. Building factors that affect sick building syndrome are high indoor temperatures which enhances fungi, low fresh ventilation which enhances producing biological contaminants, poor individual control of temperatures, poor building service maintenance and poor cleaning or cleaning ability. It is important before construction of new building to make a deep research by designers about the surrounding environment as it has a direction relationship for the location of the building in relation to the site. Using passive system design is crucial issue in reducing hazards on occupants. On the other hand using active system design should be with great careful by the designer and need a thorough study of all elements to alleviate their hazards. Finally designing using sustainable issue will give a clean environment and reduce the costs in addition to improve the indoor environment.

\section{REFERENCES}

[1] Ajayi, S., Oyedele, L. O., Alaka, H., A., owolabi, H., O., Bilal, M., Akinade, O., O., 2014, "Expository Study of Building Related Health Issues: need for Safety Measures", Bristol Enterprise, Research and Innovation Centre (BERIC), University of the West of England, Bristol, UK

[2] Grobman, Y., Amster, E., 2011, "Implications of Green Buildings and Climate Change on Human Health in Israel", Geography Research Forum • Vol. 31 • 2011: 70-82, http://grobman.net.technion.ac.il/files/2013/01/Implicationsof-Green-Buildings-and-Climate.pdf

[3] AYALP, N., 2013, "Multidimensional Approach to Sustainable Interior Design Practice", INTERNATIONAL JOURNAL of ENERGY and ENVIRONMENT, Issue 4, Volume 7

[4] Bacon, L., 2011, "Interior Designer's Attitudes Toward Sustainable Interior Design Practices and Barriers Encountered when Using Sustainable Interior Design Practices", MSc Thesis, University of Nebraska-Lincoln, lmb06m@acu.edu
[5] Abdou, O., A.; El.Kholy, G., M., Abdou, A.,A., 2006, "Correlation between Indoor Environmental Quality and Productivity in Buildings", conference:IAPS:19, http://iaps.scix.net/cgi-bin/works/Show?iaps_19_2006_732.

[6] Warsco, K., Lindsey, P., F., (2003), "Proactive approaches for mold-free interior environments", Archives of Environmental Health, 58(8), 512-522.

[7] Ko, Y., 2013, Urban form and residential energy use: A review of design principles and empirical findings, Journal of Planning Literature.

[8] Gylling, G., Knudstrup, M., Heiselberg, P., K., Hansen, E., K., 2011, Measuring sustainable homes - ARCC 2011 Considering Research: Reflecting upon current themes in Architectural Research, Detroit, MI, 20-24 April 2011.

[9] Talib, R., Ahmad, A., G., Sulieman,, M., Z., 2015, "Selected Melaka Malay traditional houses: comprehensive analysis on building defects, failures and solutions", International Journal of Emerging Trends in Engineering Research Available Online at http://www.warse.org/IJETER/static/pdf/file/ijeter 02382015.pdf

[10] Ramli, A., Akasah, Z. AMasirin, ., M. I. M., 2013, "Factors Contributing Building Safety and Health Performance of Low Cost Housing in Malaysia", Journal of Safety Engineering 2013, 2(1): $1-9$ DOI: 10.5923/j.safety.20130201.01

[11] Chohan, A. H., Che-Ani, A., I., Tahir, M.,M., Abdullah, N.,A., G., Tawil, N. M., Kamaruzzaman, S., N., 2011, "Housing and analysis of design defects: A post occupational evaluation of private housing in Malaysia", International Journal of the Physical Sciences Vol. 6(2), pp. 193-203, 18 January, 2011 Available online at http://www.academicjournals.org/IJPS DOI: 10.5897/IJPS10.347 ISSN 1992 - 1950 @2011 Academic Journals.

[12] Bell, J., Mabb, J., Garcia-Hansen, V., Bergman, B., Morawska, L., 2003, "OCCUPANT HEALTH AND PRODUCTIVITY: AN AUSTRALIAN PERSPECTIVE", International Conference on Smart and Sustainable Built Environment (SASBE 2003), 19-21 November, 2003, Brisbane.

[13] Seppanen, O., Fisk, W., J., Faulkner, D., 2004, "Control of Temperature for Health and Productivity in Offices", Lawrence Berkeley National Laboratory Environmental Energy Technologies Division Indoor Environment Department Berkeley, CA 94720, http://eetd.lbl.gov/sites/all/files/publications/lbnl-55448.pdf [14] Al Momani, H., Ali, H., H., 2008, "Sick Building Syndrome in Apartment Buildings in Jordan", Jordan Journal of Civil Engineering, Volume 2, No. 4, 2008

\section{BIOGRAPHIES}

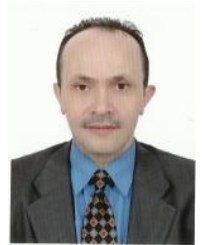

Dr. Assali received Ph.D in Architecture from Technical University of Graz (TUGRAZ) /Austia in 2001. He is from 2006till now chairperson of Interior Design Department at Ahlia University in the Kingdom of Bahrain. 